from common law or other law systems comes from the colonial period. In fact, the shari 'ah is a process rather than a code, and Mohammad Hashim Kamali ("Law, Commerce and Ethics: A Comparison Between Sharì 'ah and Common Law") is at the forefront of efforts to integrate legal systems so that Muslims may once again have the process of shari' $a h$ and not simply the name, and that relegated to the tiniest spheres of jurisdiction. In the area of Islamic banking and finance, the shari 'ah is often seen by non-Muslims as a process to be revived (p. 258).

The present work, published in the highly regarded Freiburg Studies in Social Anthropology series, is more far-ranging than can be appreciated from this review. In an age of divisions, reflected as well in academia, this work is remarkable for its scope, depth, and range of academic and intellectual perspective.

\title{
Ibrahim Ahmad Aliyu, Protection of Women's Rights Under the Shari'ah
} (Petaling Jaya [Malaysia]: Dakwah Corner, 2010), xvi+144 pp. incl. Glossary and Bibliography. ISBN 978-967-5699-02-3. MYR75.00

\section{Karim D. Crow International Institute of Advanced Islamic Studies (IAIS) Malaysia}

This relatively brief work of 135 pages is the translation of a revision of the author's book published in 2007, apparently written at the Centre for Islamic Legal Studies at Ahmadu Bello University (Zaria, Nigeria). Aliyu had completed his doctoral dissertation, entitled "Termination of Marriage and Its Legal Consequences under Islamic Law", at this Centre in 1996.

The scope of Aliyu's present work addresses the main topics of controversy over gender equality, inheritance, legal testimony, maintenance (nafaqah), women's seclusion, and political leadership. These issues feature prominently in criticisms levelled by non-Muslims concerning women's rights in Islam. The author states the aim of his book is to present a catalogue of rights which sharì ah law affords Muslim women. He undertakes to provide a clear defence of how Islamic law guarantees and protects the rights of women, and contrasts these with rights as understood from the Western perspective. The 'Publisher's Note' prefaced to this book (p. iii) alerts us to the significance of the content: "[...] Islam is not a sexist religion, do [sic] not believe in oppressing women, and most importantly, Islam preserves the right of women [sic]."

The 'Foreword' by M. Sadiq Al-Kafawy (Director, Centre for Islamic Legal Studies) refers to the critique raised in recent decades by non-Muslims which he portrays as "an outright misunderstanding of Islamic tenants [sic] mischievously created in the minds of many Muslims, especially our sisters, by the West [...] that has unfortunately found listening ears". Al-Kafawy observes that the author takes 
the offensive by portraying women in the West as being "The most imprisoned, the most enslaved and the most ravaged economically [...] she is being short-changed in virtually all her transactions" (p. vii). The author himself makes the main motive for his work plain from the start:

The issue have become controversial, among the Muslims today due to two reasons: the impact of and influence of foreign culture, especially the Western influence as well as the fact that, many of the women's rights accorded to them by Islam have been and are being violated and neglected by Muslim societies due to cultural practices or ignorance or both. And the non-compliance with Islamic principles regarding women's right has been capitalized on by the enemies of Islam, especially the West through some local and international agents so that the Muslims will be deculturalised and become more subservient and mentally enslaved to the West, perpetually. (p. xii, exact citation)

Among these local agents of the enemies of Islam singled out by the author are "the feminists and several NGOs" (p. 129), who are "blind followers" of the Western system. ${ }^{1}$ Indeed, many contemporary Muslims subscribe to this conspiracy-theory attitude of alien encroachment and (westernised Muslim) feminist subversion.

Aliyu refers to several classic Arabic legal compendia of the ahkām al-qur' 'ān and ahkām al-sharī'ah genres (al-Jassās; Ibn Ḥazm's al-Iḥkām), al- Shawkān̄̄'s Nayl al-awtār; Ibn Hazm's great compendia al-Muhallā; Ibn Qudāmah's al-Mughnī; and tafsīr works by al-Rāzī and Rashīd Riḍā. His references to classical legal works are frequently done through citations made in works of twentieth-century writers. $\mathrm{He}$ makes use of several books by the noted contemporary jurist Yūsuf al-Qaraḍāwī including his Markaz al-mar'ah fì 'l-hayāt al-islāmiyyah (2006), and by Z.-D. Sha 'bān, al-Aḥkām al-shar 'iyyah li 'l-ạ̣wāl al-shakhșiyyah (1981). More extensive are his English language sources, including five works by A.A. Maududi, Jamal Badawi's Gender Equity in Islam, and A.U. al-Faruq's The Making of a Successful Polygamy (Lagos, 2006). Thus the approach and contents of Aliyu's book provides insight into the thinking of conservative defenders of the traditional Muslim legal perspective towards status and treatment of women.

Whether the majority of traditionalist Muslims would agree with Aliyu regarding "the non-compliance with Islamic principles regarding women's right", is beyond the compass of this review. Nor is the painful question of whether "cultural practices or ignorance" contributing to rights "being violated and neglected" is merely a recent phenomenon, or has deep roots stemming from Islam's early period when Muslim jurists privileged an overbearing patriarchal interpretation of the Qur'ān and certain Prophetic utterances. The majority of contemporary Muslim religious authorities and thinkers privilege the Islamic sharī $a$ ah discourse - with its legal framing of issues marking the juridical boundaries of thought and imagination to be the most significant normative form of Islamic thought and speech. Paying 
attention to current discussions projecting traditional legal perspectives is clearly important for comprehending the centre of gravity of Muslim concerns.

Aliyu's book consists of five chapters, and here is a bare description of their contents and approach:

1. Equality and Differences between Men and Women. The very term 'gender equality' should be freed from civilisational assumptions the dominant Western perception invests it with. The true equality granted by the shari 'ah refers to spiritual and salvational equity, which admits incontrovertible biological differences confirming role-differentiation and complementarity. While spiritually equal with regard to moral responsibility, Women and Men are biologically and socially distinct with regard to occupation, social roles, and legal status.

2. Woman's General Rights. The "Basic human rights" of Woman conferred in the sources of the sharī 'ah (i.e. Qur'ān and Sunnah) include: (a) the right to life, (b) to property, (c) to basic life necessities, (d) to honour, (e) to privacy, (f) to freedom of expression, (g) the right to "a separate identity and individuality" (pp. 19-20), (h) to freedom of religion (where Aliyu digresses on topics of jih $\bar{a} d$ and apostasy), (i) to freedom of association (including "formation of women's separate organizations"), (j) to justice and equality before the law, (k) to free education, (l) and the right to choose a marital partner (although a virgin ward cannot be wed without consent from her guardian or father, along with her mother's consultation).

Aliyu's approach is well exemplified when discussing her "right to individuality".

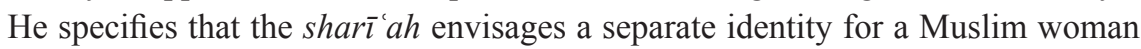
from that of a man, evidenced in her entitlement to inherit from her husband's estate while also retaining inheritance rights in her parental family. He links this with the injunction in the Qur'ān that wives should remain secluded indoors (citing 33:33: "stay in your homes [...]", ${ }^{2}$ which he understands to mean not seeking an independent life apart from her husband and family. Aliyu asserts: "It is in order to preserve and protect this individuality that women are told, in 33:33 to, as a general rule, remain indoors with dignity (and being provided for by man). [...] Staying indoors by a woman is not only considered a mark of dignity in her but a sure way of thwarting all attempts of exploiting women so long as they are properly provided for by the husbands" (pp. 19-20). It is indicative of the author's intent that at this point he resorts to quoting from Total Woman by the American Marabel Morgan, who advises her fellow women on successful marital life: "Be nice to your husband, stop nagging him and understand his needs." ${ }^{3}$ It is unlikely that many Muslim women today view home seclusion as a valued right which preserves and protects their distinct individuality - though we might be mistaken in our view.

3. Woman's Special Rights. "Due to some peculiarities and social characteristics of woman, the sharī ah has granted her some special rights" and "has imposed upon her certain special obligations" (p. 42). Aliyu divides these special rights into 
financial: provision of bridal dower (sadāq, nihlah), and of maintenance (nafaqah: feeding, clothing, shelter) by her husband; and into non-material: kind lenient treatment (as mother, wife, sister, daughter...especially with maternal relatives), sexual satisfaction from her husband (reciprocally mutual), and respecting women's chastity and modesty.

4. Differences Between the Respective Rights of the Two Sexes. This longest chapter (pp. 61-129) treats the most controversial issues relating to gender equity in Islamic legal tradition: inheritance, giving testimony, compensation for homicide or injury (diyyah, where he favourably mentions al-Qarad̄āwī's view in favour of equal compensation, against the majority of jurists), divorce (where he emphatically rebuts the view that a wife may contract a marriage empowering her to end the marriage at will), polygamy (asserting that "multiple wives of man is in accordance with the law of nature and man's temperament"), disciplining the recalcitrant wife, male guardianship over the female (al-qawämah), political leadership, serving as a judge, prohibition of wedding non-Muslim men, compulsory wearing of head scarf or hijāb, prohibition of shaking hands with men, and discouraging attendance in the congregational prayer.

Generally, Aliyu stresses in this chapter that legal differences in the treatment of women enforced by the shari ' $a h$ arise "due to differences in needs and capabilities, because the two sexes differ in functions due to their natural differences" (pp. 61-2). God created the human as 'pairs', while Qur'ān 3:36 states, “[...] the male is not like the female". Therefore, "a Muslim must believe in and accept all the physiological and psychological differences between men and women. And that it is not lawful for either of the sexes to hope to have what is naturally specific for the other or even to believe that these differences are socially created and not naturally made by the Creator." Parallel with this general principle, Aliyu strikes out at "so-called modernist Muslims in their imitation syndrome" who object to institutionalising polygamy, and he invokes many reasons why this practice is wise and practical (see pp. 82-92). Addressing these modernists "in their own craze to imitate the Westerners", Aliyu avers that "[...] they have no right to say that polygamy is not allowed, because they do not know better than Allah and his Prophet and they are not more authoritative than them" (p. 92).

5. Protection of Women's Rights. In this short chapter Aliyu describes three obstacles for protection of women's rights. One point "is the failure to see the numerous positive aspects in Muslim societies, such as family stability and cohesiveness, the respect for mothers, and sense of self fulfilment of women who are not frequently seen in public, painting a stereotypical picture of Muslim women as ignorant, submissive, oppressed and almost totally enslaved by women hating chauvinist men" (p. 131). Aliyu here makes a valid point, although the central role of the Muslim family in society is now under tremendous pressure and losing ground. 
His chief complaint regarding NGOs, international bodies and women's rights organisations is that "whenever they proffer solutions to the problem of the violation of women's rights [...] they arrogantly portray that there are no provisions in Islam regarding these rights or even if there are, they are disregarded for being outdated or unimplementable or unenforceable for not going with the so-called modern time" (p. 132). For Aliyu, such criticisms are a form of "cultural imperialism" seeking to marginalise and undermine the

supremacy of the Divine Revelation, the Qur'an and the Sunnah and sovereignty of Allah and that He is the only actual Law-giver. [... T] he injunctions and guidance of the Qur'an and the Sunnah, to Muslims, are not subject to any man-made legislation, editing, voting or modification. (p. 133)

This defensive attitude is perhaps balanced by Aliyu's brief criticism of how sharī ah-principles are distorted or disregarded in many Muslim societies today. He describes the underlying problem to consist of

trying to justify the injustices done to most Muslim women and the violation of some of their rights by religiously flavoured arguments and the assumption that the traditional and cultural practices and attitudes which are commonly used in the violation of the rights are correct and are usually followed by a selective search for endorsement in the primary sources of the Shari'ah. (p. 131)

But Aliyu carefully omits any mention of which cultural practices and attitudes result in violation of some rights, leaving it to the imagination of the reader. Is this omission because such violations are so well known? Or is it an instinctive protective reaction - in order not to draw attention to the fact that abuses or injustices affecting "most Muslim women" are wrongly excused by unfounded appeals to the authority of the sharī 'ah? This is a delicate point, given that a major criticism of Aliyu's book and his effort to ostensibly 'protect' women's rights, is his presentation of an idealised harmonising description of sharī ah-rules protective of women's rights - rules accepted by traditionalist Muslims as completely beyond questioning or criticism, yet which clash with the needs and aims of modernising societies.

The worst groups among the Muslims on whom Aliyu heaps contempt (p. 120) are the "modernists who want the Muslim world to become part of the global modernity", and the "secularists, who want the Muslim world to accept a division of religion and state in the manner of Western industrial democracies, with religion relegated to the private sphere". Faced with simplistic confusions where a glorified ideal of a perfect unchanging sharī $a h$ is arrayed against the treachery of Muslims promoting 'secular modernity', one should perhaps refrain from stating the obvious: that modernity and secularity are transforming our global reality. The real task 
Muslim thinkers must address is to reawaken the deeper understanding of the "higher aims' of the shari 'ah, bringing these maqāșid into meaningful and more adequate relation with the social reality in which Muslims exist. This creative task lies at the heart of the 'civilisational renewal' of Islam, ably exemplified by authorities like Professor Mohammad Hashim Kamali.

The author ends with a very short Conclusion: The Solution (pp. 134-5) wherein he pleads for the "sense of accountability" flowing from "the concept of trusteeship, according to which everything in this world actually belongs to Allah and those who hold it are regarded as mere trustees who are responsible in accordance with the extent of their responsibility". Aliyu urges educating the Muslims concerning these rights at the basis of safeguards guaranteeing "not only women's rights but human rights generally". This must be accompanied by the "very important safeguard" of the "duty of promoting good virtues and forbidding and fighting vices instilled in every Muslim". Now, how should this duty best be accomplished? Aliyu states that this duty "has made the Muslim to keep constant vigil on anyone who violates the limits of Allah even if it is the state" (p. 135).

One hopes that by such vigilance the author does not condone self-appointed guardians of morality exercising coercive external intervention which violates the right to privacy - so easily yielding excessive abuses of the kind well-known in certain Muslim societies. Truly, the challenge of educating faithful male Muslims and motivating them to behave responsibly with compassionate understanding towards the other half of humanity, demands far more than merely asserting a rosy idealised portrait confirming the traditional legalist discourse. It requires an interior renovation of the heart and awakening of conscience, transforming literalist legalism by means of a compassionately human spiritual Ethic.

The English translation of this work might indicate the author's hope that westernising Muslims could benefit from his work. Yet his real intended audience appears to be traditional Muslims who may be (wrongly) persuaded by modernist critiques of women's unequal treatment in Islamic legal tradition. Thus his stress on the sharī 'ah affording 'protection' to women may be understood as a sincere attempt to inoculate Muslims from contamination by inexorable global forces.

\section{Notes}

1. Aliyu states: "That female circumcision should totally be banned as being agitated by those who claim to be protecting women's rights, especially the feminists and several NGOs, this cannot be accepted and that there is no ground for its prohibition, from the point of view of the Shari "ah." Once (p. 127) the author names the American scholar-activist Amina Wadud - when treating why it is preferable for women to pray in their homes rather than attend congregational prayer in the mosque, whereas men are required to attend such prayer in the mosque. 
2. For Qur'ān 33:33 and female seclusion in the home, see the orientation by Barbara F. Stowasser, Women in the Qur'an, Traditions, and Interpretation (Oxford and New York: Oxford University Press, 1994), 97-9 and 172 n.79.

3. Aliyu (p. 20) cites Total Woman via a book by M. Wahiduddin Khan, Women Between Islam and Western Society (Karachi: Darul Ishaat, 2001), 77. This attitude is reminiscent of the polygamyadvocating 'Obedient Wives Club' which captured headlines in Malaysia in June 2011.

\section{Reinhard Cardinal Marx, Das Kapital: Ein Plädoyer für den Menschen [Capital: a plea for the human being]}

(Munich: Pattloch-Verlag, 2008; 1st ed.), 320 pp. ISBN: 978-3629021557.

$€ 19.95$

\section{Christoph Marcinkowski International Institute of Advanced Islamic Studies (IAIS) Malaysia}

The recent worldwide financial crisis ${ }^{1}$ has initiated a global fundamental debate and raised questions about the capacity of contemporary economies to ensure the welfare of the world. In October 2008, Reinhard Marx launched Das Kapital: Ein Plädoyer für den Menschen with intentional reference to the work by his namesake Karl Marx - Das Kapital: Kritik der politischen Ökonomie - an extensive treatise on political economy, edited in part by Friedrich Engels, which critiques capitalism.

Reinhard Marx, the German author of the book under review, currently serves as the Catholic archbishop of Munich and Freising and very recently (in November 2010) was elevated to the cardinalate by Pope Benedict XVI, who himself had been at the head of that archdiocese (1977-81) before his own departure for Rome. As a matter of fact, Marx (b. 1953) is now the youngest member of the College of Cardinals. Before his call to Munich in 2007, Marx served as the bishop of Trier, Germany's oldest diocese whose origins date back to the Roman period when the city was one of the imperial residences - and the birthplace of his namesake Karl Marx (to whom he is not related).

Cardinal Marx is considered to be rather conservative in matters of Church discipline, but also a social scientist and whiz with the media. He is the head of the Committee for Social Issues at the German Bishop's Conference and, since 2010, also a member of the Pontifical Council for Justice and Peace. Described as 'outspoken' and a 'larger-than-life' character who has shown a flair for mixing it up in Germany's political and media circles, the sociologist-by-training - and longtime head of the episcopate's social justice efforts - Marx had largely been viewed as in line for the archbishopric of Berlin. After an unusually protracted yearlong vacancy, however, his dispatch instead to Pope Benedict's home archdiocese places an even more pointed stamp of papal approval on Marx. Marx is now even 'traded' by some observers as potentially papabile ('popeable'), an unofficial Italian term 